\title{
"Responding to the thing that it is": a study of new play development in English theatres
}

Article

Accepted Version

Tyler, L. (2019) "Responding to the thing that it is": a study of new play development in English theatres. Studies in Theatre and Performance, 39 (1). pp. 38-53. ISSN 1468-2761 doi: https://doi.org/10.1080/14682761.2017.1348682 Available at https://centaur.reading.ac.uk/71983/

It is advisable to refer to the publisher's version if you intend to cite from the work. See Guidance on citing.

To link to this article DOI: http://dx.doi.org/10.1080/14682761.2017.1348682

Publisher: Intellect

All outputs in CentAUR are protected by Intellectual Property Rights law, including copyright law. Copyright and IPR is retained by the creators or other copyright holders. Terms and conditions for use of this material are defined in the End User Agreement.

www.reading.ac.uk/centaur

\section{CentAUR}


Central Archive at the University of Reading

Reading's research outputs online 


\title{
"Responding to the thing that it is": A Study of New Play Development in English Theatres
}

\author{
Lucy Tyler
}

Department of Film, Theatre \& Television, University of Reading, Reading, UK

Lucy Tyler

Lecturer in Performance Practices \& Industries

Department of Film, Theatre and Television

214 Minghella Building

University of Reading

Whiteknights Campus

Shinfield Road

Reading RG6 6BT

L.S.Tyler@reading.ac.uk

07806781970

Lucy Tyler's work attends to the politics of contemporary British dramaturgies.

Currently a lecturer in Performance Practices at The University of Reading and a Ph.D candidate at Royal Central School of Speech \& Drama, her research centres around curatorial and developmental dramaturgy in practice at mainstream theatres in Britain. Her work explores the labour of playmaking and the political frameworks in which theatrical processes operate. 


\section{"Responding to the thing that it is": A Study of New Play Development in English Theatres}

This paper outlines a study of play development practices in key state-subsidised English theatres in 2014 and 2015. Literary Managers, Dramaturgs and Directors were interviewed about their approach to play development in the nine theatres in which they worked: West Yorkshire Playhouse, Plymouth Drum, The Birmingham Repertory Theatre, The Mercury Theatre, The Liverpool Everyman, The Manchester Royal Exchange, The Royal Shakespeare Company, The Royal Court Theatre and The National Theatre. This paper outlines the context of this study, including an examination of existing theoretical and empirical research on contemporary, English play development. It outlines the methodology used for the data collection, presents the interview responses, and concludes with a short summary of some key findings.

Keywords: play development; new writing; dramaturgy; British theatre

\section{Introduction}

This paper explores the practice of play development in nine English theatres. Play development can be defined as the pre-production work undertaken between theatre staff and the theatre's commissioned artists. As part of my doctoral research on dramaturgies of process, over 2014 and 2015, I undertook an empirical data collection on play development in a sample of English theatres. I interviewed nine Literary Managers, Dramaturgs and Directors about their practice of play development in the theatres in which they were employed. Although their titles varied, the staff members I interviewed were all selected on the basis that they had leading roles in the preproduction development of commissioned work in their respective buildings. The nine theatres that the interviewees worked for were West Yorkshire Playhouse, Plymouth Drum, The Birmingham Repertory Theatre, The Mercury Theatre, The Liverpool 
Everyman, The Manchester Royal Exchange, The Royal Shakespeare Company, The Royal Court Theatre and The National Theatre.

I produced a set of twenty questions that I could ask the nine Literary Managers, Dramaturgs and Directors whose responsibilities centred around (or significantly included) the development of plays at the English theatres I had selected as a sample. In this paper, I will outline the context in which these interviews were undertaken, the rationale for the sample, and the methodology deployed in the collection of data. I will then use my findings to answer the central question of this paper: in my sample theatres, was a pre-existing model applied to the process of play development? If so, was it a shared model or was it unique to each theatre? Where there was a set model, was it applied consciously or unconsciously? And which job roles had responsibility for the process of play development?

These questions seemed important because they could expand on existing knowledge around how development operates in English theatres. Not only would these questions address how development operates in relation to the individual play, they would interrogate how development operates as a system. Is development an individual act, or a set of shared practices? I was keen to find out not only whether these shared principles existed, but also whether they were spoken about, or set down in any way. Was there a shared discourse that reflexively interacted with development practices? Therefore, by asking whether there was a pre-existing model of development, I hoped to find out more about the system that governed individual acts of play development at these nine theatres.

\section{Context}


Before answering these questions, it's important to highlight the ways in which this research builds on existing work in studies of play development.

There are two contexts in which play development has been explored. The first is the contemporary scholarship exploring process-based dramaturgies. The second is the set of empirical studies undertaken independently, or commissioned by Arts Council England (which I will explore in the following "Methodology" section).

While some contemporary scholarship on process-based dramaturgies has concentrated exclusively on play development in England, other studies explore models of practice across national and international contexts. Yet, despite differences in context and intentionality, studies of play development often share two central aims: first, simply to find out how play development operates and, second, to explore how this process pertains to institutional play development within state-subsidised theatres. As a result, certain theatres in this study (e.g., The National Theatre and The Royal Court) have been subject to repeated scrutiny. For example, Rosalind Haslett's “Architecture and New Play Development at The National Theatre" (2011) and Jacqueline Bolton's "Looking Back, Looking Forward: Literary Management at the Royal Court" (2008) explore play development at some of the theatres included in this study.

A different approach has been pursued by Mary Luckhurst in her book Dramaturgy: A Revolution in Theatre (2006). Luckhurst takes a "case-study" approach to explore the historical and contemporary practices of play development in England. The final chapter of Luckhurst's work, "Dramaturgy and Literary Management Today" (200-262), is an exploration of contemporary development practices at The National, The Royal Court Theatre, The Royal Shakespeare Company, The Birmingham Repertory Theatre, The Liverpool Everyman Theatre and Playhouse, The Manchester Royal Exchange and The Stephen Joseph Theatre (The Stephen Joseph is not included 
in my study, whereas West Yorkshire Playhouse, Plymouth Drum and The Mercury Theatre are). Through interviewing theatre professionals, Luckhurst collates information about the efficacy of this approach, which is comprised of pre-production work (with playwrights) on scripts, noting that a cultural cynicism towards these practices was palpable (213-4). Luckhurst contends that dramaturgy had been operating in English theatres since the nineteenth century (336). However, the increasing professionalisation of it, under the auspices of literary management, still required additional theorisation, training and further administrative efficiency.

The issues raised by Luckhurst were explored further in Turner and Behrndt's Dramaturgy and Performance (2008). In "The Dramaturg and the Theatre Institution," the authors describe and assess the formalisation of the dramaturg's role (97-120). These conversations surrounding the inception of dramaturgy, in relation to its effect on literary management and nomenclature, have been carried forward in more recent work by these theorists (Turner, 2009; Turner and Behrndt, 2010; Luckhurst, 2010). Further notable research has been undertaken by Duška Radosavljević (2013a.), Claire MacDonald (2010), and Katalin Trencsényi (2014; 2015).

The emergent discourse of dramaturgy not only added a linguistic dimension to my question (i.e., "what would 'play development' be referred to as: literary management or dramaturgy?"), but also an HR and work-related one (i.e., "what job titles would be related to play development: 'literary manager' or 'dramaturg'?” and “what responsibilities would be included under these titles?”). I was keen to establish whether the roles of literary managers and dramaturgs varied in any practical sense; did the name of the role have any influence on the models, or absence of models, applied in the development process? Had dramaturgy been "bedded down" in the sample theatres? What was its impact on working practices? Had it changed titles? Roles? What were the 
politics, or policies, of individual buildings in relation to its practice? These questions added a depth and nuance to the study, but didn't alter the central question: to what extent was a pre-existing model being applied to the process of play development?

Methodology

Existing empirical data collections of play development can be found in the work of Jacqueline Bolton (2011) and Fin Kennedy and Helen Campbell Pickford (2014). At the time the study was conducted, Jacqueline Bolton's thesis, Demarcating Dramaturgy: Mapping Theory onto Practice, was the most recent exposition of play development conducted thorough participatory research (2011). As such, Bolton's work confirmed that interviews with theatre-makers would be an appropriate approach.

In 2014, just as I was beginning my research, Fin Kennedy and Helen Campbell Pickford produced a "Delphi study" as a follow up to their important report In Battalions (2013). In Battalions offered a "snap-shot of play development at the start of 2013" (1) and the follow up Delphi study (2014) intended to continue the research by assessing the effects of Arts Council cuts on those practices. Methodologically, a Delphi study is a "systematic method of collecting opinions from a group of experts through a series of questionnaires, in which feedback of the group's opinion distribution is provided" (Helmer, 1972, 15, cited in Kennedy and Campbell Pickford, 2014, 10). Although I chose not to undertake a Delphi study proper, I decided that my interviews would benefit from the addition of a systematic questionnaire to standardise the process. However, before designing the data collection itself, I still had to choose a sample.

I had previous experience as an emerging playwright that inevitably included sending unsolicited scripts to "new writing" theatres, meetings with literary managers 
and observing staged readings. Because of these early experiences, I was in contact with several theatres that developed new writing and had been through several development systems myself, including those of Paines Plough, Hampstead Theatre and Soho. I also had experience of play development from the other side having been a reader at the Bristol Old Vic and Script in Birmingham. I was aware that if I consulted these theatres, I would bring to those interviews prior understanding that might make my analysis of the data less objective. I was wary of skewing the analysis by relying on interview data for my understanding of practices at one set of theatres, while unconsciously supplementing the interview data with my own experiences at the other set of theatres.

With the need to produce a "clean sample", I consulted empirical studies that engaged with play development at subsidised theatres in England. I hoped that in the studies undertaken by, or on behalf of, Arts Council England, I would find models that would support the construction of a methodology. Emma Dunton, Roger Nelson and Hetty Shand's New Writing in Theatre 2003-08: An assessment of new writing within smaller scale theatre in England (2008) was particularly useful because it demonstrated a sample of organisations and individuals; however, the scale - consulting 48 organisations - was beyond the scope of my study (4). But in reading Writ Large: New Writing on the British Stage 2003-2009 (2009), I came across a data set that seemed to provide a logical sample. According to Writ Large (2009), the largest producers of new writing (between 2003-08) were West Yorkshire Playhouse (5.6\%); Plymouth Drum (7.7\%); The Birmingham Repertory Theatre (8.5\%); The Mercury Theatre (4.2\%); The Liverpool Everyman (5.1\%); The Manchester Royal Exchange (5.2\%); The Royal Shakespeare Company (3.1\%); The Royal Court Theatre (4.9\%) and The National Theatre $(5.1 \%)$. Other theatres $(51 \%)$ made up the rest of the new writing produced during this period (55). 
I had set out to investigate practices at "mainstream" new writing theatres, so the studies in my sample were therefore chosen because I had no previous relationship with any of these theatres and, in the preceding period, they had undertaken the most significant play development activities. While, of course, a sample of nine theatres cannot be representative of the entire play development landscape, these theatres did cover a large number of regions and demonstrated a spread in terms of Arts Council Funding.

It was also important to reflect on why these theatres had produced the most new writing during the period covered by the Writ Large report. To find out, I consulted additional Arts Council England reports. In 2000, the Arts Council had published two reports arguing that new writing was in decline. The Boyden Report (2000) argued that text based theatre was failing to attract audiences and advocated a shift of policy that promoted new, collaborative methods of playmaking (Writ Large, 2009, 4). The following Arts Council England report of the same year, The Next Stage: Towards a National Policy for Theatre in England (2000), accepted The Boyden Report's argument and the three subsequent reports (National Policy for Theatre in England (2000), a second National Policy for Theatre in England (2002), and a new Theatre Policy (2007)) all encouraged the production of "new ways of working", "experimental" and “interdisciplinary practice” (Writ Large, 2009, 35-6). Despite an overall emphasis on the production of new work during this period, the Writ Large Report noted that "the Art Council's 2003 Theatre Writing Strategy [still] promoted initiatives that presumed a traditional relationship between individual freelance writers and producing companies" (Writ Large, 2009, 36).

I was surprised to find that in the mid-2000s some renowned new writing theatres, known for their development activities, such as The Bush Theatre or Theatre 
503, weren't producing as much new writing as other theatres that are less renowned for play development. At first, I wondered whether the theatres in my sample had received the title "most significant producers of new writing" on the basis that they had continued to produce new writing instead of new work. However, the renewed buoyancy of new writing evidenced in the sample would appear to be due to increased subsidy of all theatrical activities that had augmented the production of all types of theatre (Writ Large, 37). While this economic uplift partly accounts for the healthy production celebrated in the Writ Large Report and demonstrated by the sample, it would be interesting, in interview, to explore the impact of the attitudinal and economic shifts that the Arts Council Reports would have produced in theatre buildings and their commissioning and development practices.

Before I could contact the theatres, I needed to ensure that the study complied with established paradigms of qualitative research. Because I was conducting an ethnographic project, relying on the study of people in their own environment through observation and face-to-face interviewing, I acknowledged that I would have to take some time building up a research framework before commencing the interviews. I consulted some ethnographic examinations of dramaturgies of process. In her work Space in Performance: Making Meaning in the Theatre (1999) Gay McAuley spent a period of ten years "observing and documenting rehearsal processes and recording and analysing the subsequent performances" in order to "study the dynamic functioning of space in performance" (10-11). Although this work differed from mine in both significance and scope, I realised how, in the years preceding my study, qualitative data methods had been systematically developed and finessed by several theatre scholars, and, as a result, I was lucky to have strong examples of practice to follow. For example, 
other ethnographic studies that shaped this one included Susan Letzler Cole's Playwrights in Rehearsal: The Seduction of Company (2001), Josephine Machon's Immersive Theatres (2013) and Duška Radosavljević's The Contemporary Ensemble: Interviews with Theatre-Makers (2013b). These works not only explore theatrical process via strategies of observation and documentation, they also finesse methods of speaking to and interviewing participants in sympathetic and constructive ways with the purpose of sharing practice.

I started designing a research questionnaire that would meet with the requirements of qualitative data collection outlined in Patrica Leavy's Method Meets Arts: Arts-Based Research Practice (2009). Leavy confirms that the most effective way to conduct a broad examination of an arts practice (in my case, play development) is to collect participatory data, where interviewees discuss their own practices and perceptions (147). I compiled, as suggested, a standard open-ended interview format that would provide behaviour and opinion-based responses on play development at the theatres. Over the following months, I received positive responses and made dates to undertake the interviews. At each interview, I would start by introducing myself, ask the interviewee to sign a consent form and then ask the questions. Following each interview, I wrote up full transcripts of each exchange. The questionnaire I used is reproduced in the appendix. I added to these questions only to ask for clarification. But I often omitted a question when an interviewee had already answered it in an earlier part of the interview - in particular, the question "how do you develop a play?", produced such wholesome answers that it often made subsequent questions redundant. Otherwise, each interview used the same questions in the same order. 


\section{Findings}

To organise the findings accessibly and ethically was a difficult task. Each interview lasted approximately an hour, and each subsequent transcript averaged around 6000 words.

In this section, I have organised a selection of quotations from each individual transcript to offer a comparative overview of how each interviewee answered the first three interview questions:

1. How would you define your role at $\mathrm{x} / \mathrm{y} / \mathrm{z}$ ?

2. What are the main duties associated with the role?

3. How do you develop a play?

I have chosen to focus on these three questions for two reasons. First, the findings of these questions address the central question of this paper ("to what extent was a preexisting model being applied to the process of play development?"). Second, as mentioned before, the question "how do you develop a play?", when asked in each interview, produced such wholesome answers that it often made subsequent questions redundant.

I have organised my findings into two tables, the first documenting answers to questions one and two, the second documenting answers to question three. To best express interviewees' answers, I have quoted directly, sometimes interjecting to render the speech fully comprehensible in written form. Where I have done so, I have signalled my own interjection with brackets. At the end of each table, I will provide some analysis on how the data addresses the research questions posed by this paper. 


\section{Title and Roles}

\begin{tabular}{|c|c|}
\hline $\begin{array}{l}\text { Theatre, } \\
\text { interviewee and } \\
\text { date of interview }\end{array}$ & $\begin{array}{l}\text { Questions: "How would you define your role?" and "What are } \\
\text { the main duties associated with the role?" }\end{array}$ \\
\hline $\begin{array}{l}\text { The Mercury } \\
\text { Theatre (Tony } \\
\text { Casement, } \\
\text { Associate Director) } \\
\text { 29.08.14 }\end{array}$ & $\begin{array}{l}\text { "I started here as an actor a long time ago, but I've worked here full } \\
\text { time now for nearly ten years. And there's been a lot of change. Two } \\
\text { years ago, we had a kind-of rolling ensemble company and most of } \\
\text { the shows that we did were classics. [Now] I'm ultimately responsible } \\
\text { for our education programme [which is made up of] regular sessions } \\
\text { that we run in our building and in the community. Everything from } \\
\text { early years through [to] youth theatres [and] our playwriting group. } \\
\text { We call it our "talent development strand." }\end{array}$ \\
\hline $\begin{array}{l}\text { Plymouth Drum } \\
\text { (Jane Pawson, } \\
\text { Young Peoples' } \\
\text { Producer) } \\
10.09 .14\end{array}$ & $\begin{array}{l}\text { "I'm currently a project manager so I look after our work with young } \\
\text { people }[\ldots . . .] \text { That ranges from managing our youth theatre and } \\
\text { developing the plays on the stages. But I also manage a number of } \\
\text { projects with young people, and community work, so I've been doing } \\
\text { a lot of projects where we go into communities that we wouldn't } \\
\text { normally be able to access [...]. My area is huge. I have fifteen } \\
\text { different groups meeting every week and working through to } \\
\text { production." }\end{array}$ \\
\hline $\begin{array}{l}\text { West Yorkshire } \\
\text { Playhouse } \\
\text { (Mark Rosenblatt, }\end{array}$ & $\begin{array}{l}\text { "I direct. I directed Of Mice and Men [2014, Main House] earlier in } \\
\text { the year and I'm going to be back in here in February with a } \\
\text { Chekhov. We're commissioning a new version [of Uncle Vanya, } \\
\text { 2015, Main House]. I'm getting a writer in the room, Samuel }\end{array}$ \\
\hline
\end{tabular}




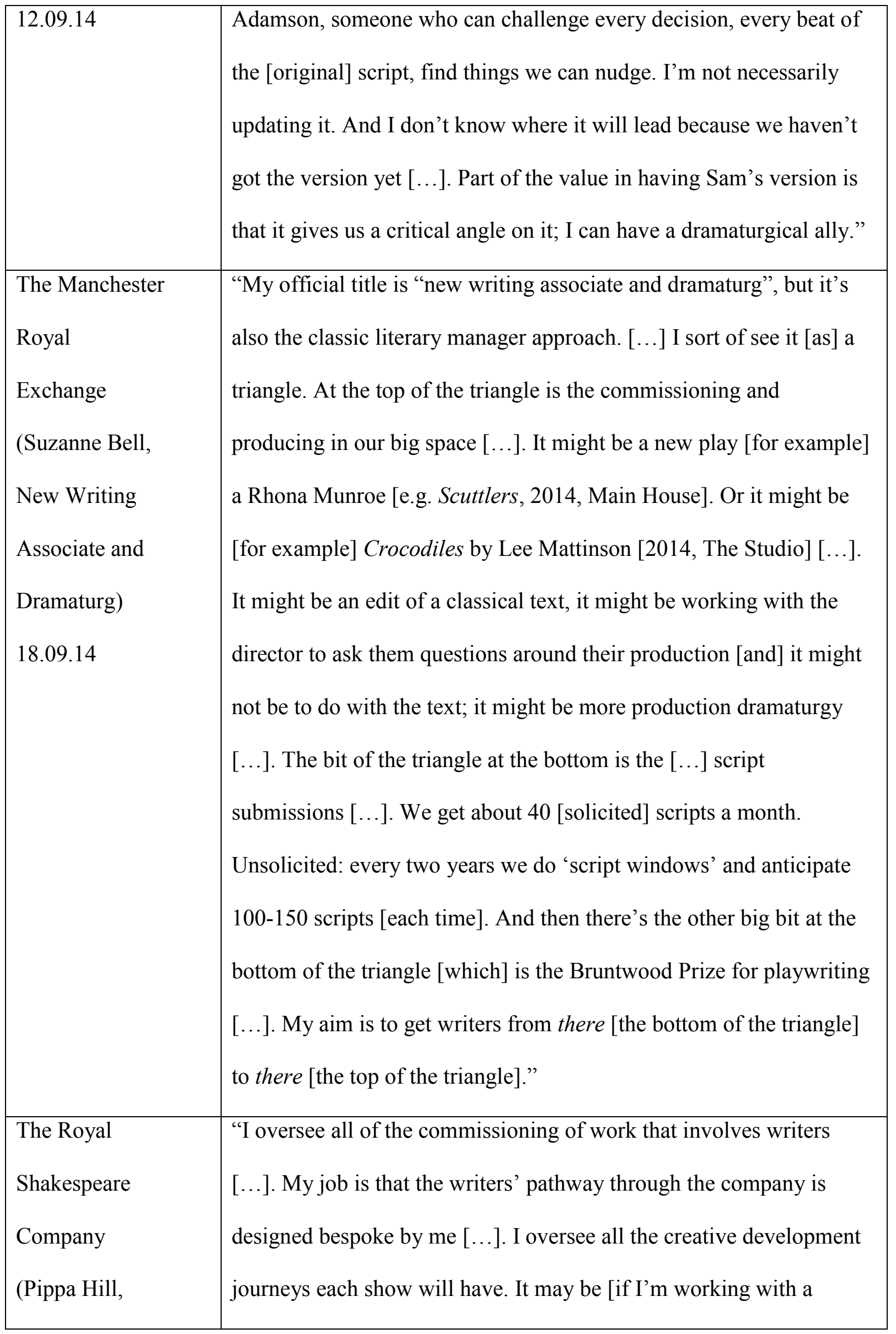




\begin{tabular}{|c|c|}
\hline Literary Manager) & $\begin{array}{l}\text { classical play, that] what I'm doing is working with a director to edit } \\
\text { a scene to make sure that the verse still works, or to make sure that } \\
\text { the changes [...] fit the production. [Or it might be] working with [a] } \\
\text { writer to develop a brand-new play [...]. At the RSC there's an } \\
\text { enormous amount of dramaturgy that happens. We did formerly have } \\
\text { a company dramaturg [Jeanie O'Hare] who's now running the } \\
\text { playwriting programme at Yale University [...]. [Now] my job covers } \\
\text { that whole umbrella." }\end{array}$ \\
\hline $\begin{array}{l}\text { The Royal Court } \\
\text { Theatre } \\
\text { (Chris Campbell, } \\
\text { Literary Manager) } \\
30.09 .14\end{array}$ & $\begin{array}{l}\text { "My role at the Royal Court is broadly in two parts. One part is to } \\
\text { deal with all our communications with playwrights from the top to the } \\
\text { bottom. Either I or my department deal with our relationships with } \\
\text { writers: reception of their scripts, response, dramaturgical advice, } \\
\text { reasons why you're doing a play, reasons why you're not doing a } \\
\text { play, managing ongoing relationships with writers from the very } \\
\text { bottom to the very top of their careers. And the other part is } \\
\text { programming the theatre. [This includes] cooperation with different } \\
\text { elements of the theatre [...]. I meet with [Vicky Featherstone, the } \\
\text { Artistic Director] to make the decisions about what we put on [...]. In } \\
\text { one sense, I sometimes think I work for the writers based at the Royal } \\
\text { Court, but I can't run away too much with that romantic idea because } \\
\text { I am also working for the theatre." }\end{array}$ \\
\hline $\begin{array}{l}\text { Liverpool Everyman } \\
\text { and Playhouse } \\
\text { (Hayley Greggs, }\end{array}$ & $\begin{array}{l}\text { "I'm the Literary Associate here at The Everyman and Playhouse. We } \\
\text { are a department of two so my manager [Literary Manager, Lindsay } \\
\text { Rodden] and I [divide] between us anything to do with new scripts or } \\
\text { new writers. We have loads of different ways to engage with writers. }\end{array}$ \\
\hline
\end{tabular}




\begin{tabular}{|c|c|}
\hline 04.11 .14 & $\begin{array}{l}\text { We send out a monthly e-newsletter [...], we read unsolicited scripts } \\
\text { [and we] run a writers' programme for } 16-25 \text { year olds. [We also } \\
\text { have a] "young writers' programme" [...]. We recently started } \\
\text { something called the "playwrights' programme" which is based on a } \\
\text { similar model to the "young writers' programme". [It's] for any } \\
\text { writer, aged } 18 \text { plus, who has some experience of writing for the } \\
\text { stage. We found that writers who [fell] into that bracket were saying } \\
\text { "I also need this training", "I also need these skills" [...]. We also } \\
\text { have writers on attachments. [We take] three writers each year who } \\
\text { we tend to have a relationship with already [...]. We've had writers } \\
\text { take their work to Brighton Fringe, or some writers take a break from } \\
\text { work and go somewhere really quiet. [...]. We run an annual new } \\
\text { writing festival which is open to all theatre makers of all levels of } \\
\text { experience [...]. There's a lot going on." }\end{array}$ \\
\hline $\begin{array}{l}\text { The Birmingham } \\
\text { Repertory Theatre } \\
\text { (Tessa Walker, } \\
\text { Associate Director) } \\
05.03 .15\end{array}$ & $\begin{array}{l}\text { "My job title is associate director. There's currently two associate } \\
\text { directors, soon to be three, and we each have very different roles. My } \\
\text { job is to direct plays, and to head up our artistic development work } \\
\text { [...]. I manage the literary department [with] one other person. We } \\
\text { run something called "The Foundry", an artist development } \\
\text { programme. [It] works with eighty playwrights and theatre-makers a } \\
\text { year from the West Midlands who are on attachment with us. I [also } \\
\text { work] closely with any artists who are currently doing work with us. } \\
\text { So that might be meeting writers to talk about their plays, it might be } \\
\text { directing work, or work with lots of companies whose primary work } \\
\text { is not writing. [I work with] makers and devisers by supporting [their }\end{array}$ \\
\hline
\end{tabular}




\begin{tabular}{|c|c|}
\hline & $\begin{array}{l}\text { practice] dramaturgically. I commission work [with] Roxana [Silbert, } \\
\text { the Artistic Director] [...]. We have a main house of } 800 \text { seats, a } \\
\text { middle space of } 400 \text { and a smaller space of } 140 \text { and I commission and } \\
\text { develop work across all of those spaces." }\end{array}$ \\
\hline Theatre (Tom & $\begin{array}{l}\text { "I might start with a caveat that [...] we're changing how we develop } \\
\text { plays. Our new department isn't going to be formed for another six } \\
\text { seven weeks [...] so now we're at the end of the old process [...]. My } \\
\text { role, as of next week, is identifying emerging talent and looking at } \\
\text { new writers so that they develop as playwrights, but, specifically, so } \\
\text { that they develop as playwrights who would one day write for the } \\
\text { National Theatre. [I'll] go out and identify writers who are doing well } \\
\text { on the fringe, or writing interesting things [elsewhere], and look at } \\
\text { ways [to] support them over [a number of] years. [This is how long it } \\
\text { takes] to do something in one of our very big spaces that have very } \\
\text { big requirements [...]. What we're going to do when we form our } \\
\text { new department [is] more formally bridge the gap between [how we } \\
\text { work with] an artist who we've identified [...] and an artist we are } \\
\text { programming in our main spaces." }\end{array}$ \\
\hline
\end{tabular}

From the above, it's possible to see that staff with development roles at these nine theatres have a variety of titles: I interviewed three "Associate Directors", one "Young Peoples' Producer", one "New Writing Associate", one "New Writing Associate and Dramaturg", two "Literary Managers" and one "Literary Associate". To what extent did an individual's job title correlate with the development activities they oversaw? 
The interviewees outlined five core development activities that were undertaken across these theatres. These were:

1) Education, outreach and talent identification.

2) Running new writing and new work groups.

3) Commissioning and programming work.

4) Pre-production work: research and development dramaturgy.

5) Production work: directing or production dramaturgy.

These activities can be grouped into pre-commission development work, focussed on the development of artists, and post-commission development work, focussed on the development of the work itself.

Those with titles relating to literary roles (e.g., "New Writing Associate", “Literary Manager”) undertook development activities that were often pre-commission development activities (i.e., activities 1, 2, 3). For example, Tom Lyons, the only "New Writing Associate" I interviewed, outlined a niche remit for his role exclusively concerned with identifying talent, either internally, via script submission, or externally, at other venues or fringe programmes. The two Literary Managers I interviewed had similarly niche responsibilities; both Chris Campbell from The Royal Court and Pippa Hill from the RSC were concerned exclusively with work around the commissioning of writers and the pre-production research and development of their scripts. Finally, the Literary Associate I interviewed, Hayley Greggs from the Liverpool Everyman and Playhouse, had a set of responsibilities around identifying talent and developing it in playwriting groups. Her responsibilities seemed to preface commissioning and postcommission research and development activity.

Those I interviewed that had titles that contained roles of "Director" or "Producer" tended toward development activities that were post-commission. For 
example, the "Associate Directors" Tony Casement at The Mercury Theatre, Mark Rosenblatt at The West Yorkshire Playhouse and Tessa Walker at The Birmingham Rep were engaged in the commissioning of work, the pre-production development of work and the production work (i.e., activities 3, 4 and 5). Although it varied between theatres, Associate Directors were also, to a certain extent, involved with pre-commission development activities. At The Mercury Theatre, for example, Tony Casement mentioned his involvement in the education strand of development activities. Similarly, at The Birmingham Rep, Tessa Walker mentioned her involvement in artist development through The Foundry programme.

Jane Pawson, the only “Young Peoples' Producer" I interviewed, undertook both pre-commission and pre-production development activities. The breadth of Pawson's activities seemed to be connected to the intended audience demographic of her work; the term "Young People" seemed to suggest diverse development activities under one umbrella term.

These findings suggest, then, that roles are usually associated with specific development activities, but aren't limited to them. Those with titles relating to "literary" practices generally undertook pre-commission development work, whereas those with titles suggesting theatrical labour (e.g. "director" or "producer") appeared to be engaged with post-commission development activities. However, in some cases, a single individual's responsibilities appeared to be diversified across all development activities. For example, the "New Writing Associate and Dramaturg" Suzanne Bell was engaged across all development activities. Bell's work, as her title suggested, spanned precommission development activities through to pre-production and production dramaturgy. Moreover, regardless of title, there were instances when a single 
individual's work spanned across all types of development activities. For example, Tony Casement defined responsibilities across all pre and post-commission development work. It's worth noting here that the evolution from literary management to dramaturgy I had been anticipating was not represented in the interviewees' job titles. Of the nine interviewees, only Suzanne Bell had "Dramaturg" as part of her title, but the title had previously been in use at the RSC (for Jeanie O'Hare). Pippa Hill inferred that while she was not known as a "Dramaturg", she now undertook the responsibilities previously undertaken by O’Hare.

The next table returns to the interviews, documented here in the same order, to explore what methods were used to undertake the development activities described in the first table.

\section{Play Development}

\begin{tabular}{|l|l|}
\hline $\begin{array}{l}\text { Theatre, } \\
\text { Interviewee and } \\
\text { date of interview }\end{array}$ & $\begin{array}{l}\text { Question: "How do you develop a play?" } \\
\text { The Mercury }\end{array}$ \\
$\begin{array}{l}\text { It depends what [play] it is, but broadly speaking, it's [our] } \\
\text { imaginative response to the material [...]. As a director [...] I'm } \\
\text { Casement, } \\
\text { Associate Director) }\end{array}$ & $\begin{array}{l}\text { into, that have strong emotional content, authentic relationships } \\
\text { [and are] theatrically dynamic. [Central to this is] the writer } \\
\text { [...]. It all stems from the script. And that's something they } \\
\text { deliver or something you [...] work on together. [A good } \\
\text { example of how I might develop a play was my production of] }\end{array}$ \\
\hline
\end{tabular}




\begin{tabular}{|c|c|}
\hline & $\begin{array}{l}\text { Amanda Wittington's Saturday Night Sunday Morning [2014]. } \\
\text { This was an adaptation that our artistic director, Daniel } \\
\text { Buckroyd, had commissioned for the company [...]. I'd seen it } \\
\text { before quite by accident so when he asked me what I'd like to } \\
\text { do I put [it] forward. It has been written to play in village halls } \\
\text { and centres and our space here is a } 500 \text { seater [...]. Amanda } \\
\text { Wittington [was] brilliant. I had a meeting with her in } \\
\text { Nottingham and said "look, these are the things I want to do. } \\
\text { Basically I want to rewrite some of your play. I want to put a } \\
\text { community choir in it as well as the eight cast members who } \\
\text { double all of the eight parts". She was fantastic [...]. We spoke } \\
\text { about it and I said "do you want to work with me on this?" and } \\
\text { she said "go ahead" [...]. It was very successful. [...] We got a } \\
\text { [4 star] review from The Guardian. We couldn't have been } \\
\text { happier. [The process was about giving a play] that had a } \\
\text { particular purpose a new life." }\end{array}$ \\
\hline $\begin{array}{l}\text { Plymouth Drum } \\
\text { (Jane Pawson, } \\
\text { Young Peoples' } \\
\text { Producer) } \\
10.09 .14\end{array}$ & $\begin{array}{l}\text { With the Youth Theatre, we do about three productions a year } \\
\text { [...]. We work across age ranges. We do [one play] with eight to } \\
\text { eleven year olds and [another that's intended for] primary-aged } \\
\text { children. [The third is] a partnership project with our youth } \\
\text { theatre [...]. This year we're working with Royal and Derngate } \\
\text { and West Yorkshire Playhouse to commission a playwright } \\
\text { [Oladipo Agboluaje] for all our youth theatres [Immune, 2015]. } \\
\text { In the development phase, [Agboluaje] will work with all three } \\
\text { cities and their young people. We've had [a development] }\end{array}$ \\
\hline
\end{tabular}




\begin{tabular}{|c|c|}
\hline & $\begin{array}{l}\text { weekend here with a lot of a debate about various different } \\
\text { issues, and tried out some workshop techniques. And then he's } \\
\text { going to do the same thing in Northampton and Leeds [...]. We } \\
\text { always say that, any time we work with a writer, we always } \\
\text { want to work on an idea that they're really interested in } \\
\text { developing. We want it to develop organically from what } \\
\text { they're interested in. Sometimes we ask "what's the next play } \\
\text { you want to write?" and if it's something that we might be } \\
\text { interested in then we'll go from there. That's the emphasis. We } \\
\text { place it on the writers. [As a result] a lot of plays have become } \\
\text { really interesting [...] covering a whole range of topics that } \\
\text { affect young peoples' lives. So we've had plays that touch on } \\
\text { racist views, divorce, fear of predators, and gender identity." }\end{array}$ \\
\hline $\begin{array}{l}\text { West Yorkshire } \\
\text { Playhouse } \\
\text { (Mark Rosenblatt, } \\
\text { Associate Director) } \\
12.09 .14\end{array}$ & $\begin{array}{l}\text { "We have a standard [process]. We have writers doing } \\
\text { workshops with directors and actors for a few days, or a week, } \\
\text { in a room. And that can take place at any point in the timeline of } \\
\text { a play's development [...]. If you're talking about a single- } \\
\text { authored commissioned play [...] everything is being offered [to } \\
\text { support the] writer. There will be a director and/or dramaturg } \\
\text { and actors giving suggestions [...]. And that is the model as } \\
\text { was. But now we're embracing a much more collaborative } \\
\text { process [...]. And there is determination to explode that } \\
\text { [traditional model]. One of our associate companies called } \\
\text { RashDash are two theatre makers who dance, and sing, and } \\
\text { write text. [They're working with a] writer who we have on }\end{array}$ \\
\hline
\end{tabular}




\begin{tabular}{|c|c|}
\hline & $\begin{array}{l}\text { attachment here, Alice Birch, to create a piece [We want you to } \\
\text { watch, 2015]. Their process is much more complicated [and] } \\
\text { time consuming. It's a group of people working out [questions } \\
\text { such as] "who is doing this?", "whose idea is leading this?" } \\
\text { [...]. And a lot of this is to do with the fact that text is not } \\
\text { always at the centre of the process. It's text and movement and } \\
\text { form [...]. So that's a very different model, but equally that has } \\
\text { lots of R\&D support and we provide that." }\end{array}$ \\
\hline $\begin{array}{l}\text { The Manchester } \\
\text { Royal } \\
\text { Exchange } \\
\text { (Suzanne Bell, } \\
\text { New Writing } \\
\text { Associate and } \\
\text { Dramaturg) } \\
18.09 .14\end{array}$ & $\begin{array}{l}\text { "It works in a lot of different ways. [...]. Most of the writers that } \\
\text { we have under commission come from quite a long relationship } \\
\text { within the company. [For example] we currently have under } \\
\text { commission Simon Stephens [Blindsided, 2014] [...]. } \\
\text { [Development models] depend on the process of the writer. We } \\
\text { [give] the space and support [for anything they might] find } \\
\text { useful [...]. That might be a workshop, and the workshop might } \\
\text { be a rehearsal room or it might be in a dance studio, or it might } \\
\text { be in a specific location. It might be here, it might be in Leeds, } \\
\text { or it might be in London [...]. It could be on our stage, or it } \\
\text { could be in a rehearsal room [...]. Some writers love workshops. } \\
\text { Others would die if they went into a workshop. Some writers } \\
\text { Some writers want a workshop with a movement director or a } \\
\text { want workshops where actors completely pull apart their script } \\
\text { and they work very freely and improvise, and other writers just } \\
\text { want a group of actors for half a day to read their work [...]. } \\
\text { sougner just so that they can unlock something." }\end{array}$ \\
\hline
\end{tabular}




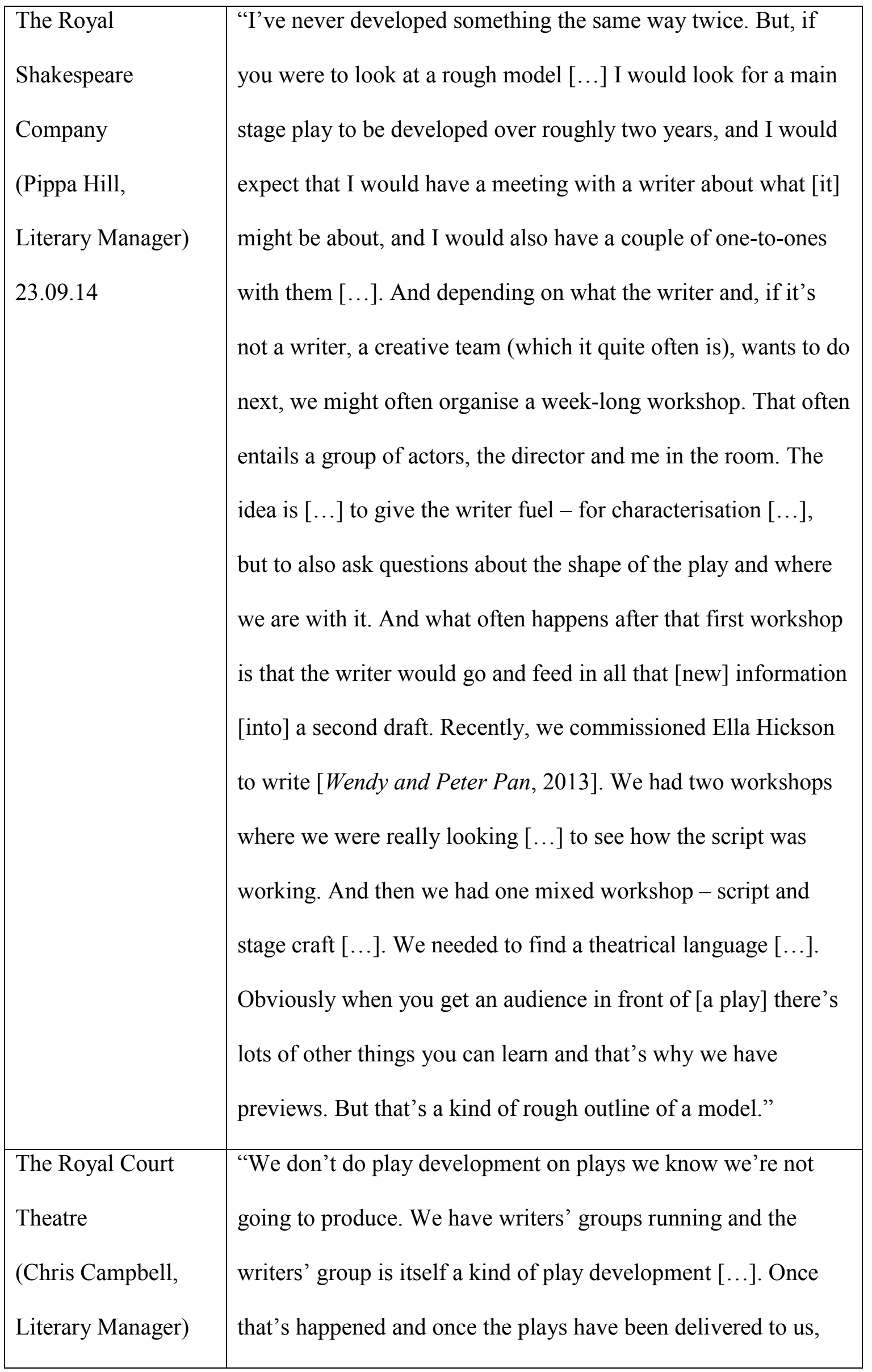




\begin{tabular}{|c|c|}
\hline 30.09 .14 & $\begin{array}{l}\text { we'll give feedback, but we won't do any more work, unless we } \\
\text { think we might produce it. That is partly because we don't have } \\
\text { the means. You know it's expensive for us to [source] actors, } \\
\text { directors [and] space to put together work [so] I don't know how } \\
\text { to develop a play if [I'm] not looking towards possible } \\
\text { production. [But in terms of a pre-production development } \\
\text { model] we [no longer] do just readings. We do a couple of days } \\
\text { and, sometimes, there'll be a reading at the end of that [leading } \\
\text { to redrafting]. Some writers, [such as] Tim Price whose play is } \\
\text { on now [Teh Internet is a Serious Business, 2014] used to write a } \\
\text { draft every week. Some people take ages and eventually produce } \\
\text { a different play. What's interesting about drafting is there are a } \\
\text { couple of writers who are so fertile that we try to stop them } \\
\text { would admit it. It's partly being so close and partly the joy of } \\
\text { writing new drafts. Some people can turn out something that is } \\
\text { essentially a different play. And, also, it's very interesting } \\
\text { because I've talked to so many writers, and watched so many } \\
\text { work, it's absolutely astounding to me how often they } \\
\text { wow whom }\end{array}$ \\
\hline $\begin{array}{l}\text { Liverpool Everyman } \\
\text { and Playhouse } \\
\text { (Hayley Greggs, } \\
\text { Literary Associate) } \\
04.11 .14\end{array}$ & $\begin{array}{l}\text { "It depends so much on where plays come from. Something } \\
\text { [such as] Scrappers by Daniel Matthews [2013] [was } \\
\text { developed] on our young writers' programme. [Daniel] } \\
\text { delivered a script [that was] really great. We decided to give him } \\
\text { a development bursary [...]. That went really well. During that }\end{array}$ \\
\hline
\end{tabular}




\begin{tabular}{|c|c|}
\hline & $\begin{array}{l}\text { year, we decided to do a rehearsed reading of Scrappers in the } \\
\text { Everyman Studio [...]. Audiences seemed to respond really well } \\
\text { towards it. It fit[ted] with the ethos of our theatres and was right } \\
\text { for our audiences now. And so we took [Scrappers] to a script } \\
\text { meeting [where] we decided that we [wanted] to produce that. } \\
\text { So that is one way to develop a play. On the other hand, [for a } \\
\text { playwright such as] Stephen Sharkey, [and his] play Sex and the } \\
\text { Three Day Week [2014], [the process is different]. We've had a } \\
\text { really long relationship with him and we know his work really } \\
\text { well. [He] pitched to Suzanne [Bell, the then literary manager] } \\
\text { [...] and because we trust his work ethic, and we trust his work } \\
\text { would be right for our stages, we went ahead and commissioned } \\
\text { him. [Not] all our commissions make it to the stage, but, on this } \\
\text { occasion, we committed to reading drafts and giving notes, and } \\
\text { finally, made the decision that this could [be commissioned]. } \\
\text { responding to the work, or responding to the writer. }\end{array}$ \\
\hline $\begin{array}{l}\text { The Birmingham } \\
\text { Repertory Theatre } \\
\text { (Tessa Walker, } \\
\text { Associate Director) } \\
05.03 .15\end{array}$ & $\begin{array}{l}\text { There really is no one way to do it. Plays are living, breathing } \\
\text { things and they'll ask very different things of you as a director, } \\
\text { as an actor, as someone working with the play in development. } \\
\text { The answer is I don't really know, but I do know that they-and } \\
\text { the people that are writing it—will need different things [...]. } \\
\text { There isn't a way to develop plays, but, there is, I suppose an } \\
\text { attitude with which you respond to the thing that it is for } \\
\text { whatever it means at that moment [...]. The word "dramaturg" }\end{array}$ \\
\hline
\end{tabular}




\begin{tabular}{|c|c|}
\hline & $\begin{array}{l}\text { is a really new word, and I don't even really know if that's what } \\
\text { I am, but I remember for a long time I just developed plays- } \\
\text { whatever play development means_-and I was directing them } \\
\text { and they were new. And then I remember suddenly there was } \\
\text { this word around, which was "dramaturg”, which people seemed } \\
\text { to be using and using it about people like myself. [We] never } \\
\text { necessarily used it ourselves. [Play development] comes about } \\
\text { entirely through practice and through a sort of "knowing" and } \\
\text { "seeing" in practice. You can't [have a model] because [plays] } \\
\text { are very complicated, brilliant shifting things. And [you realise } \\
\text { this from] being in a place like the Rep where there's a whole } \\
\text { range of artists from very different disciplines. [For example] } \\
\text { the spoken word scene in Birmingham is huge which comes out } \\
\text { of the even huger music scene in Birmingham so if you're } \\
\text { working with a spoken word artist, supporting their work, } \\
\text { they're going to need something very different from you than } \\
\text { someone starting to write [...] a play." }\end{array}$ \\
\hline $\begin{array}{l}\text { The National } \\
\text { Theatre (Tom } \\
\text { Lyons, New Writing } \\
\text { Associate) }\end{array}$ & $\begin{array}{l}\text { "The plays we develop for production are very big commissions. } \\
\text { [The writers] do the first draft. And then we read that first draft } \\
\text { [and] then that process becomes redrafting, notes, possibly } \\
\text { readings in the studio [...]. And then we look to see whether a } \\
\text { director would want to work on that project and, once we get } \\
\text { that matched up, we can look at programming the play [...]. } \\
\text { [But] small plays [are] developed quite [differently]. [For } \\
\text { example] you [might] have an [unsolicited] writer who hasn't }\end{array}$ \\
\hline
\end{tabular}




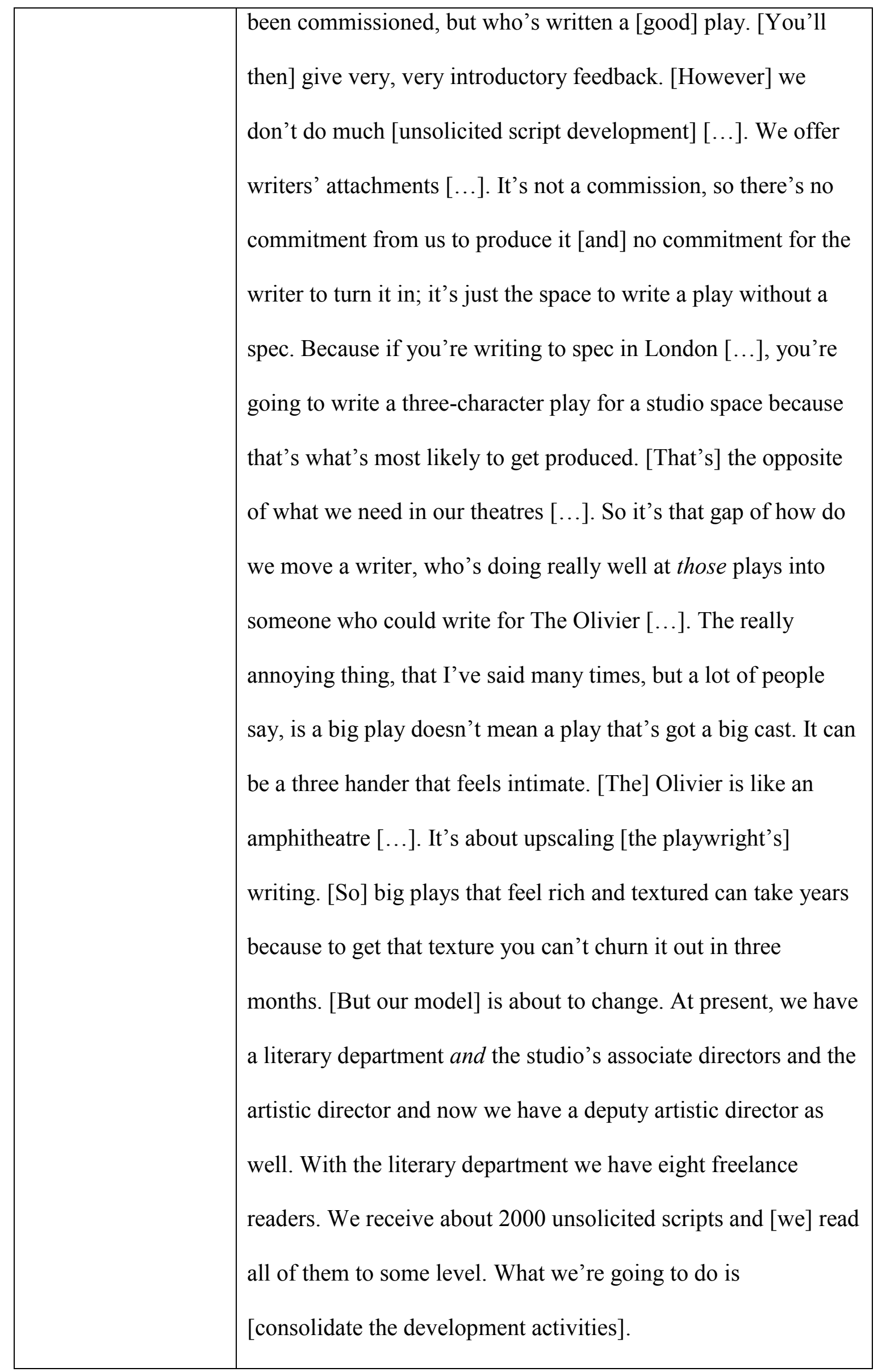


[In Autumn 2015, the Studio became the home of The National

Theatre's New Work Department, bringing the Literary

Department together with the Studio.]

The quotes in the above table suggest that two methods of play development were consciously applied at the nine theatres sampled. First, there was a shared model of play development that was applied to the development of single-authored plays: what Mark Rosenblatt describes as the "standard process" and what Pippa Hill refers to as the "rough model". Described not only by Rosenblatt and Hill, but also by Suzanne Bell and Chris Campbell, this model is a way of working with commissioned playwrights to facilitate the generating of a script prior to production. The "standard process" that, according to Hill at the RSC takes "up to two years", involves ascertaining what development support a playwright would like, then offering points of exchange around the emerging work. These might be, according to Rosenblatt, "writers doing workshops with directors and actors for a few days". According to Bell, such meetings might take place "on our stage, or in a rehearsal room". Finally, according to Campbell, the development might conclude with "a reading at the end [leading to a redrafting]". Although the variables in development models led a lot of interviewees to claim there wasn't a development model in operation in the building, actually, in all cases, there was a form shaping the process. It always involved showcasing the work at stages throughout the development phase, but that showcasing was supported by each theatre in two distinct ways. The first way is that a theatre might organise feedback on the work in development from various production perspectives. The literary manager (or equivalent), as well as directors or actors, could be called upon for professional 
perspectives on the work in development. The second way a theatre might support the showcasing process is trialling the integration of different theatrical systems. For instance, sound, lighting, design and movement work could be facilitated by the theatre to support the advancement of the work. This shared practice model for working with commissioned playwrights is undertaken within a clear, demarcated structure. This model is also alluded to by Tony Casement at The Mercury Theatre, Jane Pawson at The Plymouth Drum, and Hayley Greggs at The Liverpool Everyman and Playhouse, suggesting further the broad application of this method for engaging with commissioned playwrights.

But there is another principle of play development that is even more prominent in the interview responses. This principle works both with and against the method described above. It is the principle of constructing a method for playmaking according to the needs of the individual project: to work without a method, until one is suggested by the project in hand. As such, it is almost an anti-method. As Tony Casement at The Mercury Theatre says, development "depends". Jane Pawson at The Plymouth Drum reiterates this fluid, unstructured approach: "we want it to develop organically." And Suzanne Bell at The Manchester Royal Exchange confirms that "it works in lots of different ways.” Tessa Walker at the Birmingham Rep summed it up by defining development as an attitude, defining the practice as "respond[ing] to the thing that it is".

"Respond[ing] to the thing that it is" is a sentiment of development that was espoused by everyone I spoke to. Given this fluid approach to development, what factors determine how any piece of work will be developed? While it's possible to take seriously the claim that each piece of work undergoes a unique development, actually, 
there is a process informing development and that process is, to an extent, determined by where the work has come from, and where the work is going.

Regarding where the work has come from, commissioned projects take three main forms. In the first type of commission, plays are commissioned from playwrights. These are original dramas (e.g., Simon Stephens' Blindsided (2014) for the Manchester Royal Exchange) that immediately suggest the use of the traditional development model described above. However, there are two other commissioned forms that require a different approach. The second type of commission is work produced by the building itself, usually with external support or consultation (e.g., Tony Casement's directorial rewriting of Amanda Whittington's adaptation of Alan Sillitoe's Saturday Night Sunday Morning (2014)). The final type of project is the new work commissions undertaken by a range of artists (e.g., RashDash at The West Yorkshire Playhouse). The variation in commission produces a variation in the development process.

As regards where the work is going, interviewees reported that the development process was influenced by the intended performance space. At the Royal Shakespeare Company and The National, interviewees remarked on the care taken during development to help the artists acclimatise to the peculiarities and scale of the spaces. At The Mercury Theatre and The Birmingham Rep, there was acknowledgement that work had to develop in relation to the space in which it would be performed. And, in addition to having a unique physical geography, each space also has its own reputation, and this also influenced the development process. For instance, at The Liverpool Everyman, Hayley Greggs described how commissioning and development had to "fit with the ethos of our theatres and [what] was right for our audiences now".

In addition to protecting its creative reputation with audiences and critics, each theatre also seeks to uphold its reputation among artists who might work there. A fluid 
approach to development is perhaps more appealing to artists than a bureaucratic or micro-managed alternative. And a fluid approach seems to introduce a location of care into the process. According to Hayley Greggs, a fluid approach is necessary because "it depends so much on where plays come from." There is a sense that the material conditions, wellbeing and career trajectory of an artist or company need to be acknowledged in the creative process.

Finally, it's important to comment on the way in which "dramaturgy" was referred to by these interviewees. Although the title "dramaturg" had not been adopted at most of these theatres, the noun "dramaturgy" was used to describe certain aspects of development. Often, it was used to describe the shared labour of development between staff and commissioned artists: the act of working together. At the West Yorkshire Playhouse, for example, Mark Rosenblatt used the phrase "dramaturgical ally" to refer to the collaborative efforts that he and playwright Samuel Anderson would soon undertake in their production of Uncle Vanya (2015). At The Royal Court, Chris Campbell talked about the "dramaturgical advice" being offered to playwrights from the theatre's staff, and, at The Manchester Royal Exchange, Suzanne Bell mentioned the "production dramaturgy" she might undertake with commissioned artists. Overall, then, models of development are deployed at these theatres to support the development of diverse projects. A fluidity of process is paramount, but what's also important here is the sense of collaboration captured in the use of the word "dramaturgy": play development is conceptualised as the shared labour of creating.

\section{Conclusion}


The theatres I sampled are materially different; they have separate histories, often intertwined with city identities. They have different visions, different income streams and different working practices. The professionals I interviewed had different job titles, and their roles in the development process, while overlapping, had different emphases.

Nevertheless, they reported applying two main methods to the process of play development. First, there was what Mark Rosenblatt described as the "standard process" applied to the development of single-authored plays. The "standard process" was not a rigid homogenous template - its application was flexible and varied within and between theatres - but each incarnation of this process existed in dialogue with a pre-determined model that understood playmaking as a journey of improvement from commissioning to production via showcasing and refinement. However, there was another model of development that was practiced and protected across each theatre: the method of not structuring the development process. This can almost be called an anti-model because its central tenet is an explicit resistance to applying pre-conceived models. Instead, it advocates methodological fluidity and celebrates the importance of finding a bespoke strategy for each piece of art. In the above section, I discussed some of the practical reasons why interviewees favoured a flexible approach that could respond to different types of commissions, designed for different types of spaces. But there's also a suggestion that this flexibility challenges some more traditional and restrictive methods (real or imagined): at the West Yorkshire Playhouse, Rosenblatt described a "determination to explode" the "standard process" in favour of "embracing a much more collaborative process".

It would be interesting to continue this enquiry and to discover whether this celebration of developmental flexibility correlates with the emergence of new forms of work. By prioritising a flexible development model over a traditional single-author 
development approach, theatres may be contributing to an evolution of form through a conscious broadening of development methodology. And yet, in advocating a fluid and responsive anti-model of play development, many respondents were careful to emphasise the power and centrality of the author: according to Tony Casement at The Mercury Theatre, "it all stems from the script"; at the Plymouth Drum, Jane Pawson said, "we place [the emphasis] on the writers"; at the Manchester Royal Exchange, Suzanne Bell said that development has to "depend on the process of the writer"; while according to Hayley Greggs at the Liverpool Everyman, "it all boils down to responding to the work, or responding to the writer."

So, as a final reflection, it's worth noting that while this study offers insights into the development activities and methods at nine theatres, it is, in some senses, a necessarily limited account that relies on practitioners' self-presentation of their development activities: what people say about their work and how they do it. This doesn't mean that what interviewees said was untrue, or unrepresentative, but it does mean that other narratives may coexist. For instance, it's impossible to know from the data collected here whether commissioned artists feel they are central to determining the development process. There is therefore scope for a more sustained ethnographic examination into how the fluid approach to development espoused by respondents in my sample relates to practical working experiences in these theatres. 
Appendix

Interview: Playmaking Processes and Development

\section{You and Your Role}

1. How would you define your role at $\mathrm{x} / \mathrm{y} / \mathrm{z}$ ?

2. What are the main duties associated with the role?

\section{Play Development - You and Your Institution's Processes}

3. How do you develop a play?

4. How did this model emerge?

5. Is this a bespoke process/formalised process?

6. If you had to lineate the process, how would you chronologise it?

7. How long is a development process?

8. Who's involved?

9. Could you rate them in order of importance to the process?

10. Where is the work developed?

\section{Your Opinions on Development}

11. What do you think your most successful play development model/experience is to date?

12. When you're developing a piece, are there wider concerns shaping the way you're treating it?

13. When you're developing a play, what would you say is your main responsibility?

14. To what extent are you willing to contribute to the creative work? 
15. What, in your experience, is the artist's role (in developing the work)?

16. Have you ever encountered a piece that doesn't require development? If so, what?

17. Have you ever had to change your typical developmental process for any reason?

18. What other ways to develop work do you use/ know about?

19. What aspects/moments of play development are you particularly interested in? Why?

20. In your opinion what is the most important aspect of any play development? 


\section{Reference List}

Arts Council England. 2009. Writ Large: New Writing on the British Stage 20032009. Accessed 01.04.1 http://www.artscouncil.org.uk/sites/default/files/downloadfile/Writ Large New Writing on the English_Stage 2003-2009.pdf

Bolton, Jaqueline. 2008. "Looking Back, Looking Forward: Literary Management at the Royal Court." Contemporary Theatre Review 18 (1): 137-140. doi: 10486801

Bolton, Jaqueline. 2011 Demarcating Dramaturgy: Mapping Theory onto Practice. PhD diss., University of Leeds.

Dunton, Emma, Roger Nelson and Hetty Shand. 2008. New Writing in Theatre 2003-08: An assessment of new writing within smaller scale theatre in England. Accessed 01.04,17 http://www.artscouncil.org.uk/sites/default/files/downloadfile/New_writing_theatre_2003-8.pdf

Haslett, Rosalind. 2011. "Architecture and New Play Development at The National Theatre.” New Theatre Quarterly 27 (4): 358-367. doi:10.1017/S0266464X11000674

Kennedy, Fin and Campbell Pickford, Helen. 2013. In Battalions: A Snap-Shot of New Play Development at the start of 2013. Accessed 01.04.17 https://drive.google.com/file/d/0B0yB2pxxhJH-OXVBb2ZCSnFsYlk/view

Kennedy, Fin and Campbell Pickford, Helen. 2014. In Battalions Delphi Study. Accessed 01.04.17 https://www.scribd.com/document/203083584/In-BattalionsDelphi-Study

Letzler Cole, Susan. 2001. Playwrights in Rehearsal: The Seduction of Company. Great Britain: Routledge.

Leavy, Patricia. 2009. Method Meets Art: Arts-Based Research Practice NYC: The Guildford Press.

Luckhurst, Mary. 2006. Dramaturgy: A Revolution in Theatre. USA: Cambridge University Press.

Luckhurst, Mary. 2010. "Dramaturgy and Agendas of Change: Tinderbox and the Joint Sectoral Dramaturgy Project.” Contemporary Theatre Review 20 (2): 173184. DOI: $10.1080 / 10486801003682377$

Machon, Josephine. 2013. Immersive Theatres. China: Palgrave Macmillan.

McAuley, Gay. 1999. Space in Performance: Making Meaning in the Theatre. USA: University of Michigan Press.

MacDonald, Claire. 2010. "Conducting the flow: Dramaturgy and writing" Studies in Theatre and Performance 30 (1): 91-100. doi: 10.1386/stap.30.1.91/1 
Radoslavjević, Duŝka. 2013a. Theatre-Making: Interplay between Text and Performance. Hampshire: Palgrave Macmillan.

Radoslavjević, Duŝka (ed). 2013b. The Contemporary Ensemble: Interviews with Theatre-Makers Oxon: Routledge.

Trencsényi, Katalin (ed). 2014. New Dramaturgy: International Perspectives on Theory and Practice. India: Methuen.

Trencsényi, Katalin. 2015. Dramaturgy in the Making: A guide for Practitioners. Suffolk: Methuen.

Turner, Cathy and Behrndt, Synne. 2008. Dramaturgy and Performance. USA: Palgrave.

Turner, Cathy. 2009. "Getting the 'Now' into the Written Text (and vice versa): Developing dramaturgies of process." Performance Research 14 (1): 106-114. DOI: $10.1080 / 13528160903113270$

Turner, Cathy and Behrndt, Synne. 2010. "Editorial." Contemporary Theatre Review 20 (2): 145-148. DOI: 10.1080/10486801003690628

\section{Interviews}

Suzanne Bell, New Writing Associate and Dramaturg at The Manchester Royal Exchange, unpublished interview with Lucy Tyler. 18.09.14.

Chris Campbell, Literary Manager of The Royal Court Theatre, unpublished interview with Lucy Tyler. 30.09.14.

Tony Casement, Associate Director of The Mercury Theatre, unpublished interview with Lucy Tyler. 29.08.14.

Hayley Greggs, Literary Associate at the Liverpool Everyman and Playhouse, unpublished interview with Lucy Tyler. 04.11.14.

Pippa Hill, Literary Manager at The Royal Shakespeare Company, unpublished interview with Lucy Tyler. 23.09.14.

Tom Lyons, New Writing Associate and Dramaturg at The National Theatre, unpublished interview with Lucy Tyler 12.05.15

Jane Pawson, Young Peoples' Producer, Plymouth Drum, unpublished interview with Lucy Tyler. 10.09.14.

Mark Rosenblatt, Associate Director at The West Yorkshire Playhouse, unpublished interview with Lucy Tyler. 12.09.14.

Tessa Walker, Associate Director at The Birmingham Repertory Theatre, 
unpublished interview with Lucy Tyler. 05.03.15. 